\title{
FUNCTIONAL COMPOSITE NANOFIBERS DERIVED FROM NATURAL EXTRACT OF SATUREJA HORTENSIS
}

\author{
Hazal GERGEROĞLU ${ }^{1}$, Hüseyin AVCI ${ }^{2, *}$ \\ 1 Department of Nanotechnology and Nanoscience, Graduate School of Natural and Applied Sciences, \\ Eskişehir Osmangazi University, Eskişehir, Turkey \\ 2 Department of Metallurgical and Materials Engineering, Faculty of Engineering and Architecture, \\ Eskişehir Osmangazi University, Eskişehir, Turkey
}

\begin{abstract}
Development of environmentally friendly and natural-based products with healing properties has become a popular trend for human health. Here, for the first time as far as known, we reported an efficient antibacterial composite nanofiber which was functionalized with the herbal extract of Satureja hortensis $(\mathrm{SH})$ via electrospinning technique for wound care dressing applications. The plant which was used for this purpose is cultivated on a commercial scale in our country, Turkey, and it is relatively inexpensive and widely used. Investigation of the herbal extract demonstrated $227 \%$ higher antibacterial activity against Staphylococcus aureus and $141 \%$ higher for Pseudomonas aeruginosa when compared with a commonly used strong antibiotic of amoxicillin. Thermoplastic polyurethane (TPU)-based composite nanofibers including SH with a diameter of about $734 \mathrm{~nm}$ for the wound dressings also showed efficient antibacterial activity against these two pathogens which can lead significant health problems and deaths. FTIR characterization confirmed that there is no chemical change of SH when it was incorporated to the composite polymeric nanofibers by the electrospinning technique. We strongly believe that the obtained results suggest a potential natural-based eco-friendly approach for wound care dressing in contrast with synthetic and metal based-antibacterial agents, which have many negative effects on human body and the environment.
\end{abstract}

Keywords: Herbal extract, Nanofiber, Electrospinning, Antibacterial, Wound dressing

\section{INTRODUCTION}

Types and structures of wound dressing have an important role for healing. Traditional dressings have several disadvantages such as low mechanical properties, lack of antibacterial activity with inadequate oxygen and water vapor permeability. Ideal non-toxic dressing should keep humidity around the wound having antibacterial activity and oxygen permeability. It should be capable of aiding appropriate dermal repair and epidermal support [1,2].

Some of the wounds are spontaneously repaired in time. During this time, many organizations like wound moisture regulation mechanism; preventing tissue water loss and tissue death, reducing the sensation of pain, the formation of blood vessels (angiogenesis), the destruction of dead tissue and fibrin, regulating growth factors and providing the relationship between the target cells are made simultaneously. Despite all these advantages, healing time sometimes increases because of pathogenic microorganisms which emerge around the wound [1,2]. One of the most important pathogenic microorganisms is a member of the genus Staphylococcus, which is called as Staphylococcus aureus can cause mucosal tissue injury, infection and surgical intervention. It is well known that Gram-positive $S$. aureus can produce a virulence factor which causes skin and soft tissue infections, common skin rashes infections, sepsis and endocarditis, organ infections that could result in life-threatening situations and serious deadly infections [3]. On the other hand, Pseudomonas aeruginosa is another important human pathogen can proliferate patients whose immune system is suppressed in their respiratory and urinary tract, burn and open wounds to delay wound healing process. P. aeruginosa is a type of gram- 
negative and belongs to Pseudomonadaceae family under gamma proteobacteria class. It can produce virulence factors and cystic fibrosis which lead serious illness in burned people who are potentially open to the infection [4]. In addition, despite the use of powerful antibiotics against these bacteria, they can cause serious infections and death ranged from $18 \%$ to $61 \%$ [5]. In order to prevent delays of healing by $S$. aureus and $P$. aeruginosa formed around the wound, effective antibacterial wound dressings are needed to kill and inhibit the growth of these microorganisms.

Recently, traditional wound dressings and medical textiles containing antibacterial agents provide a more effective mechanism and accelerate the wound healing process. Many studies state that materials with potent antibacterial properties like povidone iodine, silver, and chemical antibacterial agents such as gentamicin sulfate can be combined with nanotechnology to be used in many applications. However, the negative effects on people and the environment are one of the most important problems of these chemical agents during their use and disposal. Therefore, there is a need to investigate the toxic effects of these materials on cellular metabolic activities [1,5]. It could be argued that the development of natural antibacterial agents has become one of the most important areas in order to resolve this growing concern [6]. In addition, the rapid increase in world population and environmental pollution, researchers are focused on the development of new sanitary products in recent years with minimum adverse effects on the environment. Instead of using metal and chemical biocides which show many problems due to their side effects, utilizing herbal extracts as antibacterial agents have been studied broadly.

Ramalingam et al. used electrospinning method to produce poly (2-hydroxyethyl methacrylate) p(HEMA) nanofibers containing different concentrations of curcumin. They reported that these nanofibers had high antibacterial activity against E. coli and $S$. aureus bacteria [7]. In another study, functionalized PCL/PVP nanofibers were produced by the electrospinning method by combining Tecomell undulata plant extracts which have therapeutic property for wound healing against typical hospital pathogens of P. aeruginosa, S. aureus, and E. coli [8]. Sadri and his colleagues conducted a study in 2015 about wound healing properties of chitosan/polyethylene oxide (PEO) nanofibers containing natural and eco-friendly green tea extract as the antibacterial agent. They investigated strong antibacterial activity for $E$. coli and $S$. aureus. They also investigated wound healing abilities of the nanofibers in vivo mouse skins by using nanofibers contained chitosan/PEO/green tea extract. As a result, the medical feature of the herbal based antibacterial agent can keep the wound moist surfaces, reducing inflammation, and it plays a crucial role in accelerating the healing and treatment process [9]. Avci et al. investigated Lawsonia inermis (henna) extract from their dry leaves to combine PVA and PEO nanofibers by electrospinning process. It was observed that composite fibers with henna extracts demonstrated effective antibacterial activity against $E$. coli and $S$. aureus bacteria. They stated that environmentallyfriendly antimicrobial agents such as L. inermis extract can be a potential treatment material [6].

It can be argued that the discovery and the development of natural-based products for the medical applications is one of the most important phenomena of 21st-century. An important example is that Prof. Tu Youyou was awarded 2015 Nobel Prize in Medicine for discovering artemisinin from a pure substance using extracts of the herbs to treat malaria. One of the reasons of using plants for medical and pharmaceutical development is that they contain essential oils in their structure which have therapeutic properties. Medical plants contain mainly shrubs, trees, herbs and climbers. In the case for Lamiaceae satureja hortensis (thyme) has essential oils which contain bitter substances and tannins [10]. Plant extract of SH with having high antibacterial properties attract the attention of many researchers even if different rates of components are formed on the same types due to the local and regional differences. Adigüzel and his colleagues investigated the antibacterial properties of essential oil from SH that is grown in Artvin flora in Turkey. It was gained by water-steam distillation then observed the performance against 42 different microorganisms. The main components which are thymol about $40.54 \%$ and $18.56 \%$ $\gamma$-terpinene from the essential oils demonstrated effective antibacterial activity by disrupting permeable barrier of the cell membranes of the microorganisms and prevented the inhalation [11]. Oussalah et al. also studied 28 different essential oils gained from plants to investigate antibacterial activities against 
four pathogenic bacteria (E. coli, L. monocytogenes, S. Typhimurium and S. aureus). One of the plants which they used to achieve an essential oil was the flower of SH from France origin showed the highest potent antibacterial activity in all types of the bacteria [12].

Wound dressings are usually manufactured in a variety of structures by solvent casting, gas foaming, freeze drying, nanofiber networks via using different methods such as electrospinning, porous films, sponges, hydrogels and hydrocolloids [1,2]. Electrospinning is a popular method which is applying electric fields to obtain fibers from microscale to ultra-fine nanoscale using both natural and synthetic polymers, ceramics, and composites [13-15].

In this study, SH plant extract from Turkey flora was used as an effective antibacterial and therapeutic agent against $S$. aureus commonly seen in human wound burns and $P$. aeruginosa found extensively in skin flora. The plant extract was then combined with TPU which is widely used in the medical field to obtain nanofiber wound dressing via electrospinning method. This composite nanofiber with the antibacterial activity was reported for the first time in the literature. Furthermore, resulted composite functionalized nanofibers were investigated for morphology and functional groups by performing SEM and FTIR characterization.

\section{MATERIALS AND METHODS}

\subsection{Materials and Characterizations}

Thermoplastic polyurethane (Elastollan C95A) was obtained from BASF. Dimethylformamide (DMF) anhydrous grade was obtained from Sigma-Aldrich. SH plant we used is Balıkesir origin, Turkey. All materials were used as received.

Electrospinning process was carried out using commonly used simple electrospinning apparatus to obtain nanofiber wound dressings. The morphological features of nanofibers were investigated by a scanning electron microscope (SEM). IR spectra were recorded using FTIR for resulted composite nanofibres.

\subsection{Obtaining of Plant Extracts}

Steam distillation was employed for the isolation of extract by using SH seeds with a Clevenger apparatus. The resulting herbal extract was completely dried under closed dark conditions hence it did not contain any impurities from the outside. In addition, a higher antibacterial activity of the extract was obtained by the extraction process using distilled water instead of ethanol; therefore, the extraction process was followed by the distilled water.

\subsection{Preparation of Solutions for Electrospinning}

Electrospinning solutions were prepared by using DMF solvent containing $15 \mathrm{wt} . \%$ TPU at $25^{\circ} \mathrm{C}$ with constant stirring of $500 \mathrm{rpm}$ until obtaining completely dissolved colorless solution.

Electrospinning process for nanofiber production was optimized after many trials under $60 \%$ humidity, at $20^{\circ} \mathrm{C}$, by applying the voltage of $24 \mathrm{kV}, 20 \mathrm{~cm}$ distance between the syringe and collector with the feeding rate of $0.2 \mathrm{ml} / \mathrm{hr}$.

\subsection{Obtaining Composite TPU/SH Nanofibers}

DMF solvent containing $15 \%$ wt. TPU and $10 \%$ dry SH extract were stirred at room temperature with a magnetic stirrer rotation speed of $500 \mathrm{rpm}$ for 24 hours till obtaining homogeneous solution. The resulting herbal extract-polymer solution for electrospinning process optimization studies was adjusted 
Gergeroğlu and Avcı/Anadolu Univ. J. of Sci. and Technology A-Appl. Sci. and Eng. 18 (5) - 2017

to $63 \%$ moisture content at about $21^{\circ} \mathrm{C}$ temperature, applied voltage of $20 \mathrm{kV}$, the distance of $16 \mathrm{~cm}$ and the feeding rate of $1 \mathrm{~mL} / \mathrm{h}$.

\subsection{Antibacterial Analysis}

Antimicrobial activities of the herbal, composite and pure nanofibers against gram-positive (S. aureus) and gram negative ( $P$. aeruginosa) bacteria were performed by using disk diffusion method followed by the AATCC 147-1998 test parameters. For this test, the bacteria were inoculated in Nutrient broth and incubated at $37^{\circ} \mathrm{C}$ overnight. After incubation, each microorganism was prepared with McFarland 0.5 standards $(1.5 \mathrm{x} 108 \mathrm{CFU} / \mathrm{mL})$. Test materials were added each plate and these plates incubated at $37^{\circ} \mathrm{C}$ for $24 \mathrm{~h}$.

The zone of inhibition was measured and compared after incubation time. The amoxicillin used as a positive control for bacterial species as a commercial control for the antimicrobial assay.

\section{RESULT AND DISCUSSION}

\subsection{SEM Analysis of Nanofibers}

Morphological properties of resulting virgin and composite TPU-based nanofiber were examined by SEM images. Figure 1 shows the virgin and composite TPU-based nanofibers containing the plant extract.

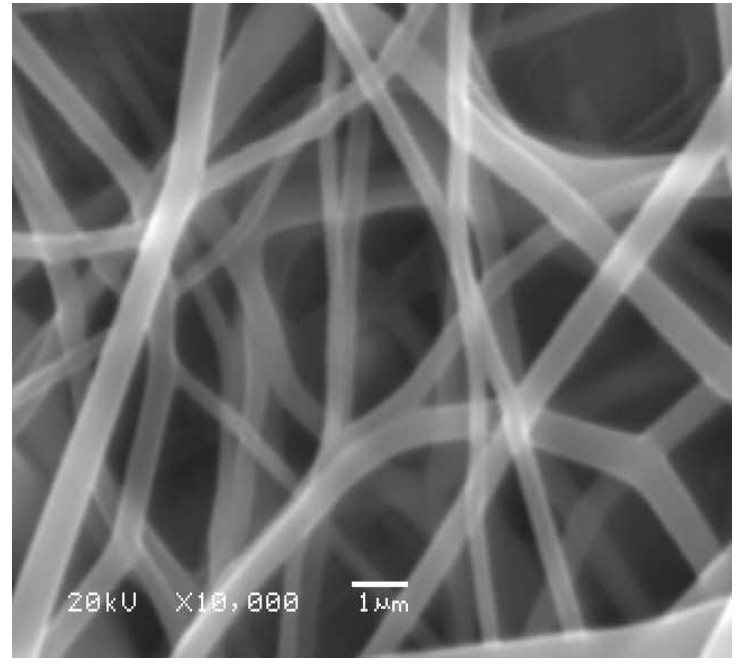

(a)

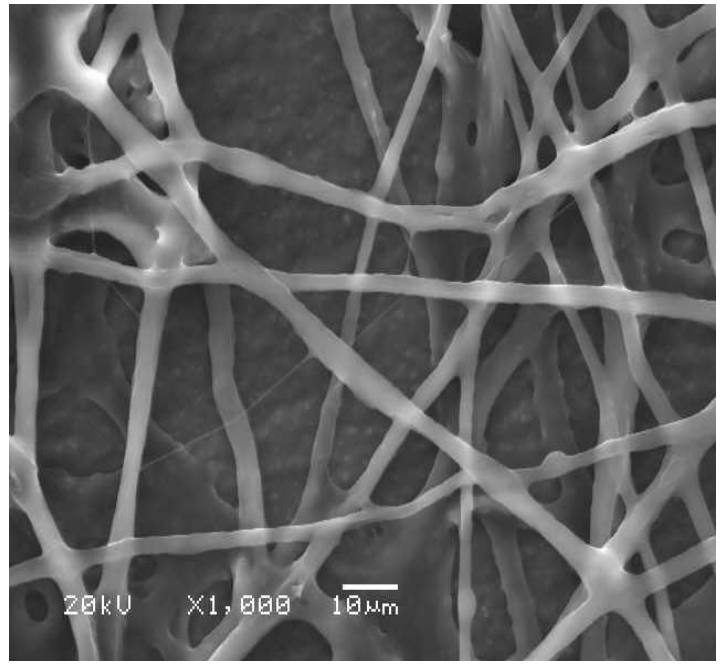

(b)

Figure 1. SEM images of (a) virgin TPU and (b) TPU/SH composite nanofibers

Morphological analysis has been performed via ImageJ program using at least 50 nanofibers from different spots on the web with the average diameter of $314 \pm 51 \mathrm{~nm}$ for virgin nanofibers and $1701 \pm 749$ $\mathrm{nm}$ for composite TPU/SH nanofibers. With the addition of SH plant extract, the diameter and standard deviation of the composite nanofibers increased. The most important reason is probably integration of the plant extracts into the fibers, and also it is very important evidence for the composite fibers which contain the plant extract. On the other hand, numerous attempts have been performed to reduce the composite fiber diameter, and finally optimization process parameters were achieved (Table 1 and Figure 2). The effect of process parameters on nanofiber diameter by SEM analysis shown in Table 1 were examined. The resulting diameter of the nanofibers was measured and is shown in Table 2 from at least 50 different locations. 
Gergeroğlu and Avcı / Anadolu Univ. J. of Sci. and Technology A-Appl. Sci. and Eng. 18 (5) - 2017

Table 1. Parameters for optimization study for decreasing diameters of the nanofibers

\begin{tabular}{cccc}
\hline $\begin{array}{c}\text { Polymer \& } \\
\text { sample ID }\end{array}$ & $\begin{array}{c}\text { Feeding rate } \\
(\mathrm{mL} / \mathrm{hr})\end{array}$ & $\begin{array}{c}\text { Electrospinning Proses Parameters } \\
\text { Applied voltage } \\
(\mathrm{kV})\end{array}$ & $\begin{array}{c}\text { Distance between syringe needle and collector } \\
(\mathrm{cm})\end{array}$ \\
\hline A & 1 & 22 & 20 \\
B & 2 & 20 & 18 \\
C & 2 & 25 & 22 \\
D & 1 & 22 & 19 \\
E & 1 & 18 & 18 \\
F & 2 & 22 & 20 \\
\hline
\end{tabular}

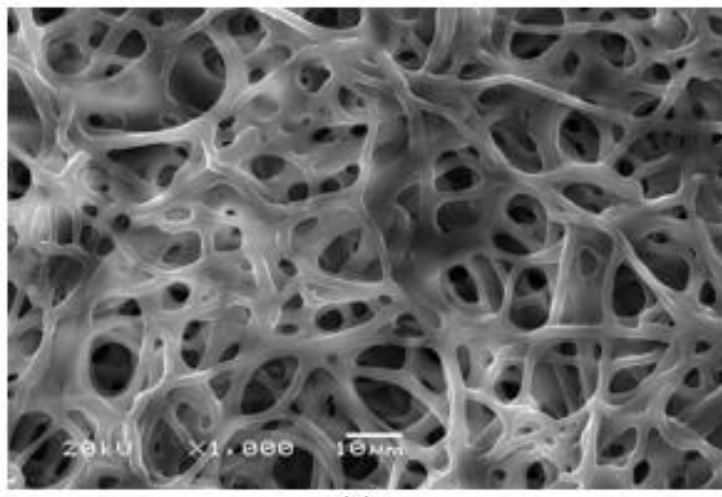

(a)

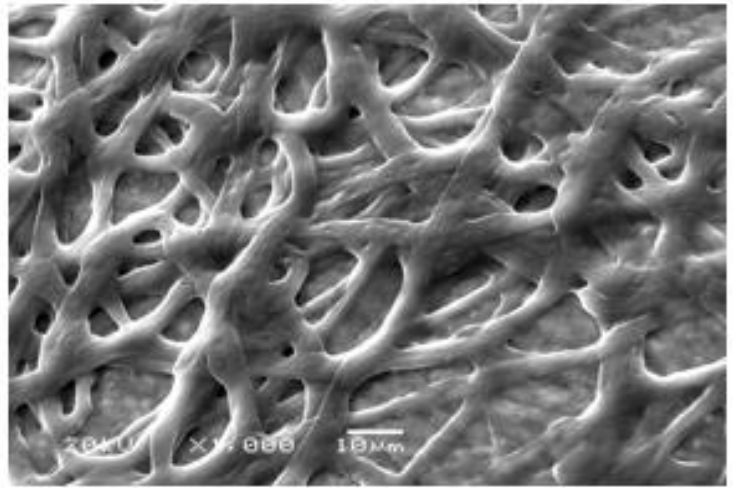

(c)

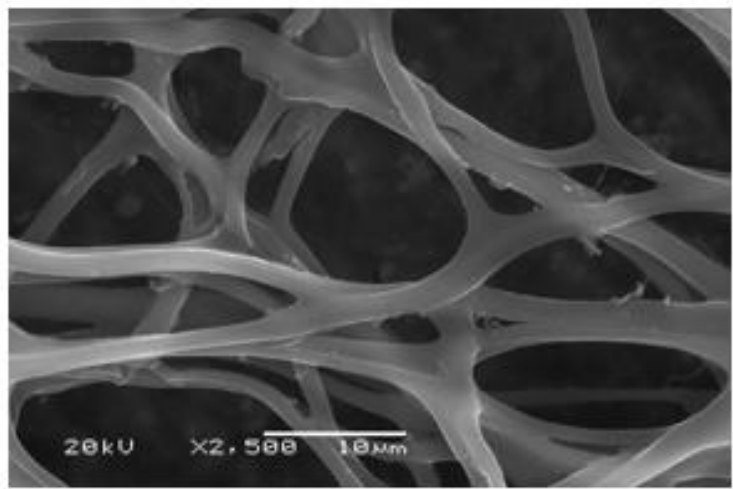

(e)

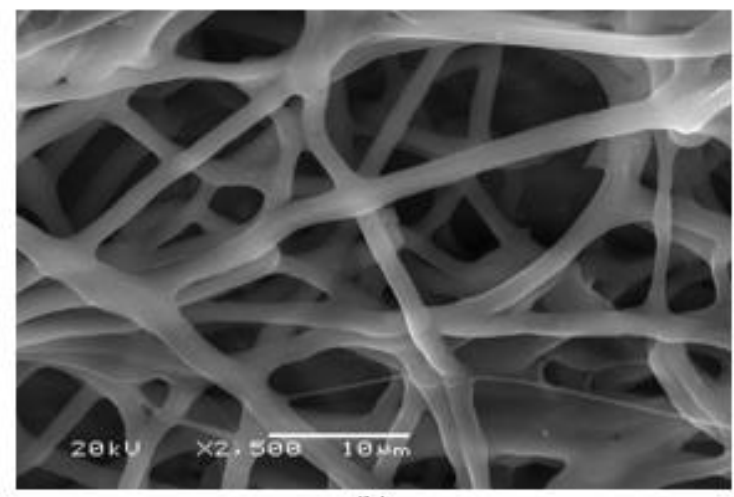

(b)

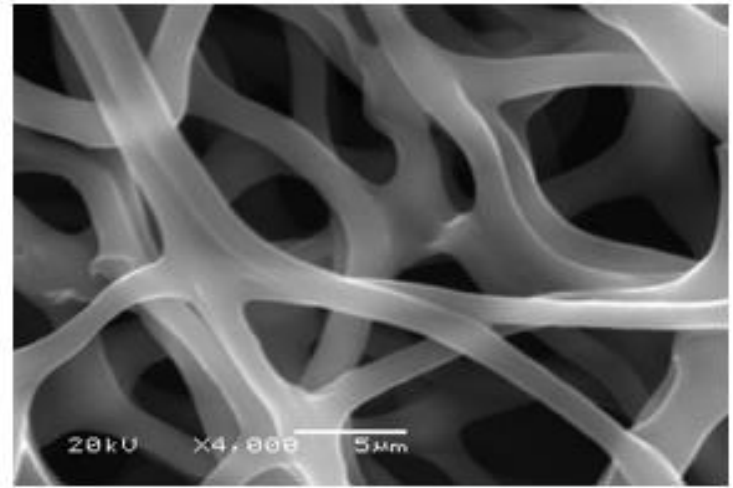

(d)

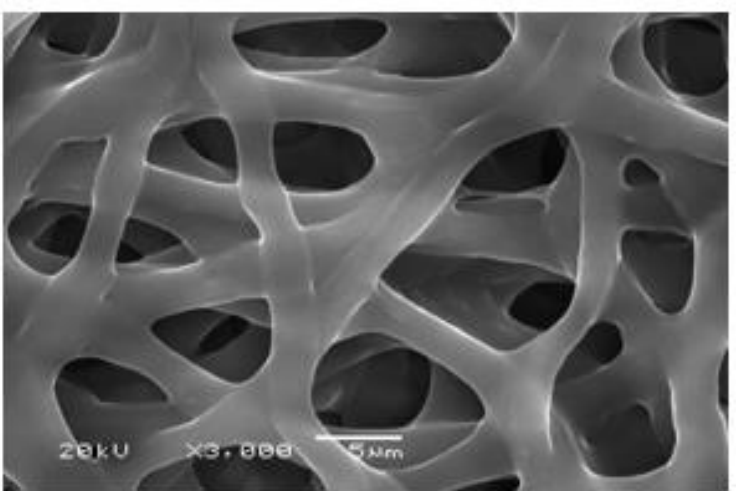

(f)

Figure 2. SEM images of nanofibers from different electrospinning parameters according to Table 1 
Gergeroğlu and Avcı/Anadolu Univ. J. of Sci. and Technology A-Appl. Sci. and Eng. 18 (5) - 2017

Table 2. Diameters of nanofibers after applying different electrospinning conditions

\begin{tabular}{cc}
\hline Sample ID & Nanofiber diameter $(\mathrm{nm})$ \\
\hline A & $1203 \pm 161$ \\
B & $734 \pm 145$ \\
C & $3322 \pm 761$ \\
D & $1013 \pm 112$ \\
E & $955 \pm 131$ \\
F & $2051 \pm 292$ \\
\hline
\end{tabular}

Optimum results from different parameters showed that the applied voltage of $20 \mathrm{kV}$ at $18 \mathrm{~cm}$ of the distance with the flow rate of $2 \mathrm{ml} / \mathrm{hr}$ is the best condition which is designated as B fiber. It has the average diameter of about $735 \mathrm{~nm}$. As a result, the findings of the present study demonstrated even if the diameter of the composite fibers containing the herbal extract can be decreased to a certain degree. It is hard to obtain the similar diameter distribution range of the virgin polymer because of the existence of the plant extract.

\subsection{Antibacterial Analysis}

The antibacterial performance of nanofibers functionalized with the plant extracts was analyzed by disk diffusion method. According to the literature, if any material is considered as bactericidal, the zone of inhibition should be bigger than $6 \mathrm{~mm}[16,17]$. In addition, the percentage increases for the antibacterial activities when we compared with amoxicillin. It was determined according to Table 3 by using the following equation:

$$
\%(\text { increase })=\frac{(S-A)}{A} \times 100
$$

where $S$ is the clear zone of inhibition of the extract or nanofibers in $\mathrm{mm}$, and $A$ is the clear zone of inhibition of amoxicillin in $\mathrm{mm}$.

As seen in Figure 3, there is no antibacterial activity when a pure polymeric nanofiber was performed; however, the composite nanofibers containing plant extract demonstrated clear inhibition zones against the gram-positive and gram-negative bacteria. Moreover, Table 3 demonstrates that the plant extract indicates $227 \%$ higher antibacterial activity against S. aureus, and about $141 \%$ higher performance against $P$. aeruginosa bacteria in the terms of the zone of inhibition when we compare the commonly used synthetic powerful antibiotic of amoxicillin with completely natural SH plant extract. It is strongly believed that higher concentration of SH in electrospinning and extract solutions will show even more antibacterial activity $[6,18,19]$. 
Gergeroğlu and Avcl / Anadolu Univ. J. of Sci. and Technology A-Appl. Sci. and Eng. 18 (5)-2017

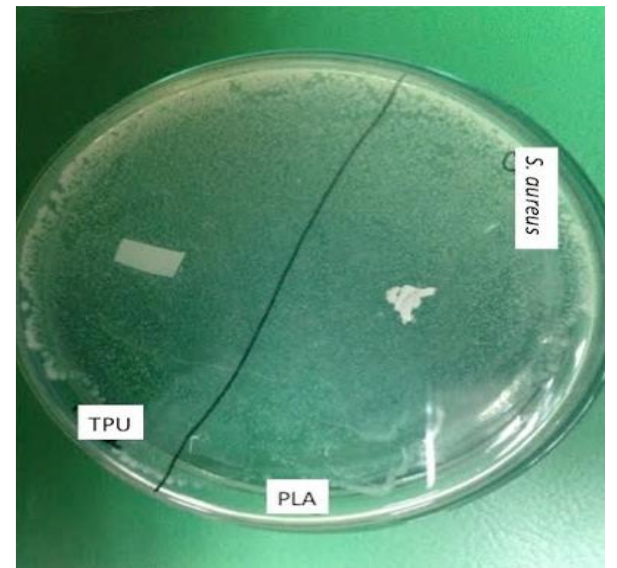

(a)

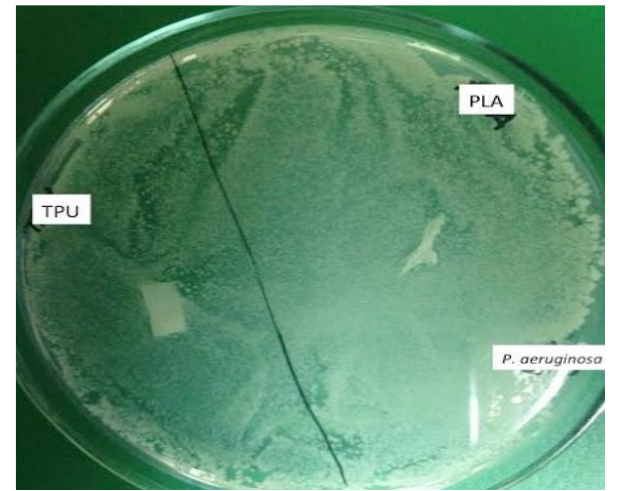

(c)

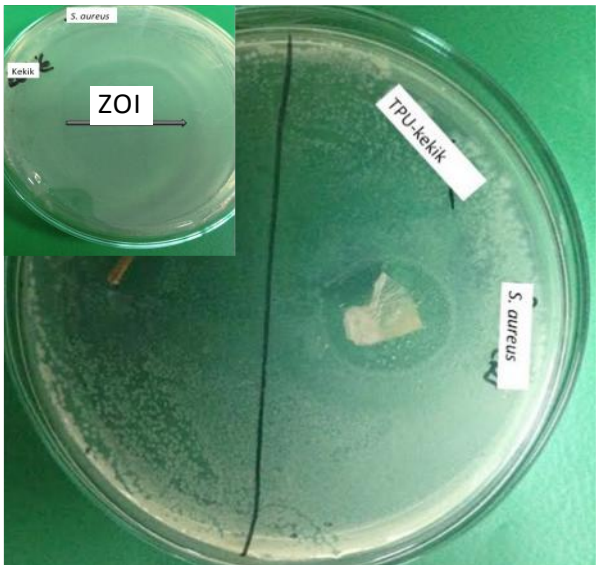

(b)

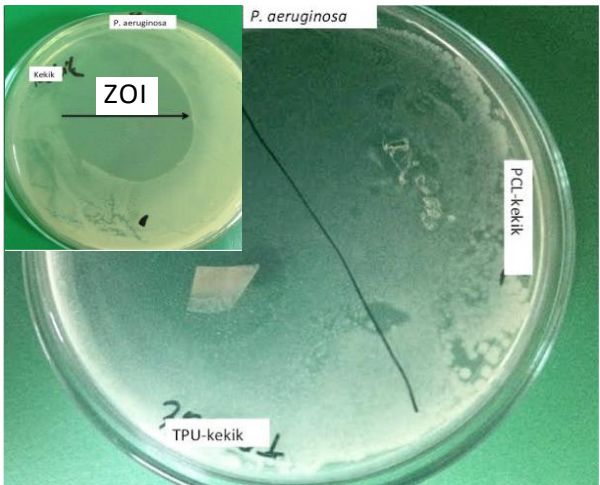

(d)

Figure 3. Photograph images of antibacterial activities of pure SH extract, virgin TPU and composite TPU/SH nanofibers (a) Virgin TPU nanofibers against $S$. Aureus. (b) The pure SH (inset image) and composite TPU/SH nanofibers against $S$. Aureus. (c) Virgin TPU nanofibers against P. Aeruginosa microorganisms. (d) The pure SH (inset image) and composite TPU/SH nanofibers against $P$. Aeruginosa microorganisms.

Tablo 3. Zone of inhibition data for the extract and for the nanofibers

\begin{tabular}{ccc}
\hline Samples & Zone of inhibition $(\mathbf{m m})$ \\
\hline & S. Aureus & P. Aeruginosa \\
Amoxicillin & 15 & 22 \\
Virgin SH extract & 49 & 53 \\
Virgin TPU nanofibers & 0 & 0 \\
Composite TPU/SH nanofibers & 18 & 22 \\
\hline
\end{tabular}

\subsection{FTIR Analysis}

It has been proved by FTIR characterization that the presence of the extract in the composite TPU/SH nanofibers remained almost the same when we compared with the peaks corresponding to the pure extract. Furthermore, it was verified that there was no chemical change in the SH when it was incorporated to composite polymeric nanofibers by the electrospinning technique. 
As shown in Figure 4, FTIR of SH plant extract determined the wavenumber range from 600 to 4000 $\mathrm{cm}^{-1}$. A clear band in the region with the peak of $815 \mathrm{~cm}^{-1}$ was observed which corresponds to the aromatic $\mathrm{C}-\mathrm{H}$ group; at $996 \mathrm{~cm}^{-1}$ is correlation with $=\mathrm{C}-\mathrm{H}$ bond; $1120 \mathrm{~cm}^{-1}$ is from the $\mathrm{C}-\mathrm{N}$ stretching, the peaks of 1424 and $1593 \mathrm{~cm}^{-1}$ are from C-N stretching; and the peaks of about 2963 and $3266 \mathrm{~cm}^{-1}$ correspond $\mathrm{C}-\mathrm{H}$ and $\mathrm{O}-\mathrm{H}$ stretching, respectively. It is also thought the presence of specific peaks in the SH plant extract related to thymol and carvacrol components, which are considered for the antibacterial activity.

An FTIR spectrum of virgin TPU nanofibers is shown in Figure 5 with the wavenumber range from 600 to $4000 \mathrm{~cm}^{-1}$. In this case; the peaks of $1080,1225,1314,1533,1735,2971,3362 \mathrm{~cm}^{-1}$ correspond to C$\mathrm{O}$ stretching, C-N stretching, N-O symmetrical bond, N-O asymmetrical bond, $\mathrm{C}=\mathrm{O}$ stretching, $\mathrm{C}-\mathrm{H}$ and $\mathrm{N}-\mathrm{H}$ stretching, respectively. Virgin TPU in Figure 6 and TPU/SH composite nanofibers were compared, and it is resulted that the TPU characteristic peaks did not change when SH herbal extract was incorporated to TPU nanofibers. It demonstrated that these additional peaks are the most probably associated with the presence of SH components in the TPU nanofibers without any change.

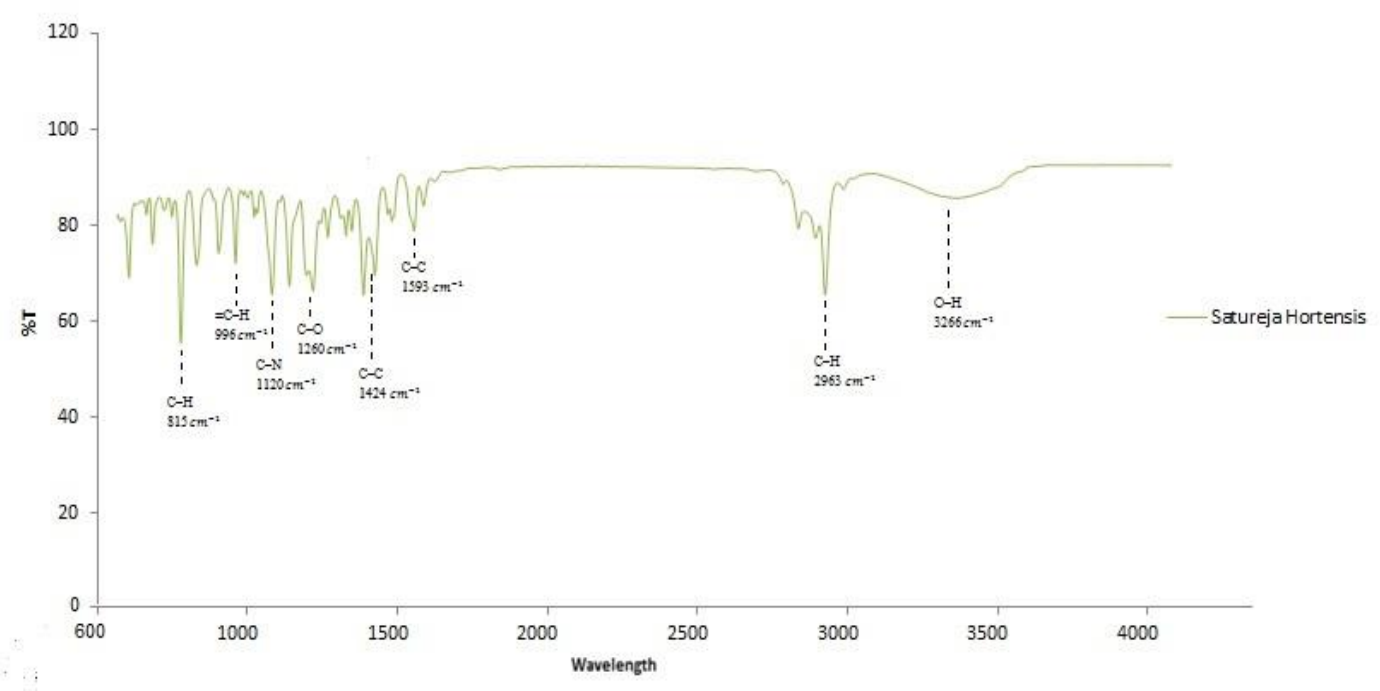

Figure 4. FTIR spectrum of virgin SH extract

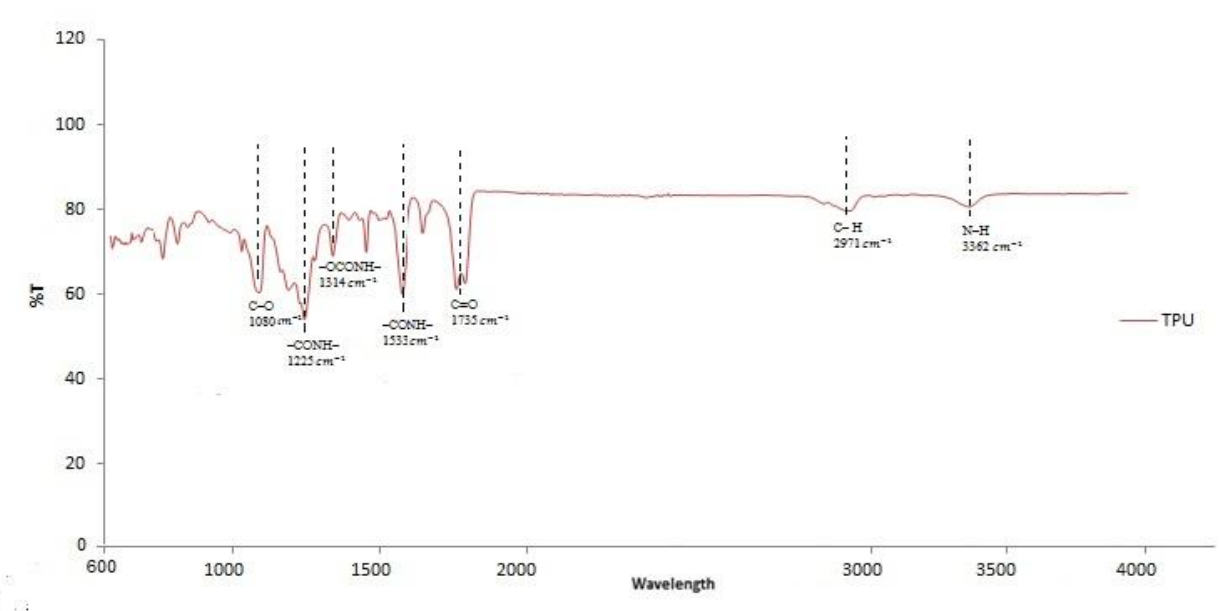

Figure 5. FTIR spectrum of virgin TPU nanofibers 


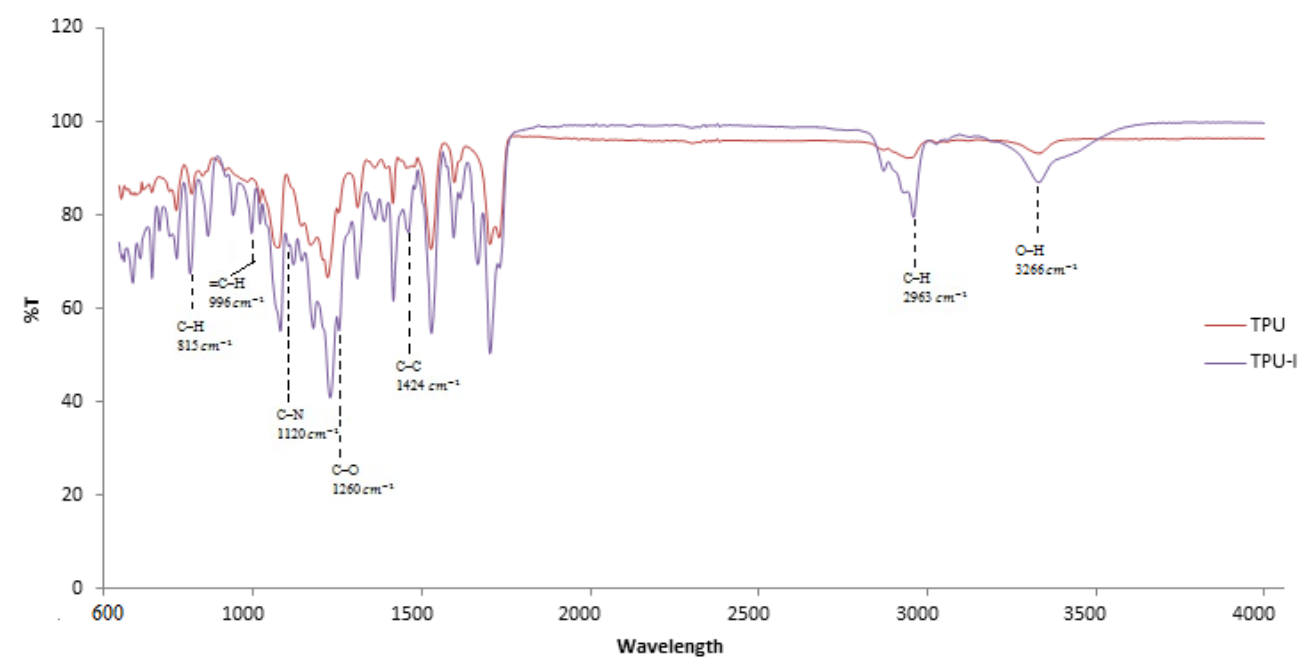

Figure 6. FTIR spectrums for the comparison of virgin TPU and composite TPU/SH nanofibers

\section{CONCLUSION}

S. hortensis plant, which is cultivated in Turkey, is relatively cheap and widely available. S. hortensis simply extracted with only distilled water and demonstrated significant zone of inhibition of 49 and 53 mm against S. Aureus and P. Aeruginosa, respectively. Gulluce et al. [20] obtained S. hortensis plant extract by using methanol as a solvent. After the investigation, they only observed $11 \mathrm{~mm}$ zone of inhibition for $P$. Aeruginosa and did not realize any zone for $S$. Aureus. In addition, Sahin et al. [21] performed a study with almost the same plant and extraction procedures by using hexane and methanol but collected the plant in a different region of Turkey. However, the results showed that the extracts via both extraction procedures did not have any antibacterial activity for these two bacteria types. Findings in those studies supported the observations of the similar trend when we used ethanol extraction in our research. In the case of the ethanol extract, the maximal inhibition zones values of these bacterial strains sensitivity were 5 and $15 \mathrm{~mm}$ for $S$. Aureus and P. Aeruginosa, respectively. Based on these results, it is possible to conclude that the type of extraction solvent and the plant origin are important parameters in order to maximize the antibacterial activity.

In our study, the extract was successfully incorporated to TPU nanofibers without any chemical change based on the FTIR results, which can be used a potential medical product as a potent eco-friendly wound care dressing with economically profitable for the health sector. The composite fibers also demonstrated an effective bactericidal efficacy against $S$. aureus and $P$. aeruginosa. S. hortensis extract can easily release as a "leaching" antimicrobial agents while in contact with infected skin area or damaged wound area of the body. Moreover, to the best of our knowledge, there has not been any published scientific data that combined S. hortensis extract with TPU nanofibers.

On the other hand, amoxicilline is a very efficient antibiotic against a wide range of infection types, therefore, it is broadly used in the world. We showed that the herbal extract and the composite nanofibers include the extract has more effective antibacterial activity than amoxicilline.

The average diameter of electrospun composite nanofibers increased from about $314 \mathrm{~nm}$ to approximately $734 \mathrm{~nm}$ after adding the extract to the structure. Increasing the diameter of nanofibers presumably due to integration of the compounds into the fibers. Moreover, this evidence is vitally important in addition to FTIR analysis shows that the composite fibers contain the plant extract. It is strongly believed that the additional peaks from the extract are related to thymol and carvacrol which have potent antibacterial activity [22-24]. 
Gergeroğlu and Avcı/Anadolu Univ. J. of Sci. and Technology A-Appl. Sci. and Eng. 18 (5) - 2017

This work provided a novel and unique universal strategy for the construction of cost effective, environmentally friendly, and natural composite nanofiber-based structures that promote open wound healing process.

\section{ACKNOWLEDGEMENTS}

The authors gratefully acknowledge the ESOGU Scientific Research Fund (ESOGU-BAP grant number 2014-614) for the financial support of this research.

\section{REFERENCES}

[1] Phaechamud T, Issarayungyuen P, Pichayakorn W. Gentamicin sulfate-loaded porous natural rubber films for wound dressing. Int J Biol Macromolec 2016; 85: 634-644.

[2] Namazi H, Rakhshaei R, Hamishehkar H, Kafil S.H. Antibiotic loaded carboxymethylcellulose/MCM-41 nanocompositehydrogel films as potential wound dressing. Int J Biol Macromolec 2016; 85: 327-334.

[3] Karataş E. Çeşitli klinik örneklerden izole edilen Staphylococcus Aureus suşlarında antibiyotik direnç genleri ve panton-valentine lökosidin varlığının araştırılması. MSc, Gaziantep University, Gaziantep, Turkey, 2015.

[4] Tekerci M. Sinop ve çevre illerdeki kliniklerden izole edilen pseudomonas aeruginosa suşlarının tanısı ve antibiyotik dirençliliğinin belirlenmesi. MSc, Sinop Üniversitesi, Sinop, Turkey, 2015.

[5] Zieminska E, Struzynska L. Zinc modulates nanosilver-1nduced toxicity in primary neuronal cultures. Neurotox Res 2016; 29:325-343.

[6] Avci H, Monticello R, Kotek R. Preparation of antibacterial PVA and PEO nanofibers containing Lawsonia Inermis (henna) leaf extracts. J Biomater Sci Polym Ed 2013; 24(16): 1815-1830.

[7] Ramalingam N, Natarajan TS, Rajiv S. Preparation and characterization of electrospun curcumin loaded poly(2-hydroxyethyl methacrylate) nanofiber- A biomaterial for multidrug resistant organisms. J Biomed Mater Res Part A 2015; 103A:16-24.

[8] Suganya S, Senthil Ram T, Lakshmi BS, Giridev VR. Herbal drug incorporated antibacterial nanofibrous mat fabricated by electrospinning: An excellent matrix for wound dressings. J Appl Polym Sci 2011; 121(5): 2893-2899.

[9] Sadri M, Sorkhi SA, Vatani H, Pebdeni AB. New wound dressing polymeric nanofiber containing green tea extract prepared by electrospinning method. Fiber Polym 2015; 16(8): 1742-1750.

[10] Özderin, S, Fakir H, Dönmez IE. Muğla-Ula yöresinde doğal yayılış yapan bazı kekik türlerinin uçucu yăg oranları ve bileşenlerinin belirlenmesi. In: II. Ulusal Akdeniz Orman ve Çevre Sempozyumu; 22-24 October 2014; Isparta, Turkey. pp. 96-103.

[11] Adiguzel A, Ozer H, Kilic H, Cetin B. Screening of antimicrobial activity of essential oil and methanol extract of Satureja hortensis on foodborne bacteria and fungi. Czech J Food Sci 2007; 25: $81-89$. 
Gergeroğlu and Avcı/Anadolu Univ. J. of Sci. and Technology A-Appl. Sci. and Eng. 18 (5) - 2017

[12] Oussalah M, Caillet S, Saucier L, Lacroix M. Inhibitory effects of selected plant essential oils on the growth of four pathogenic bacteria: E. coli O157:H7, Salmonella Typhimurium Staphylococcus aureus and Listeria monocytogenes. Food Control 2007; 18: 414-420.

[13] Raghavan P, Lim DH, Ahn JH, Nah C, Sherrington DC, Ryu HS, Ahn HJ. Electrospun polymer nanofibers: The booming cutting edge technology. React Funct Polym 2012; 72(12): 915-930.

[14] Erdem R, Sancak E, Elektroçekim yöntemiyle elde edilen poliamid 6/kitosan bazlı nanoliflerin morfolojik özelliklerinin incelenmesi. İstanbul Ticaret Üniversitesi Fen Bilimleri Dergisi 2013; 12(4): 53-65.

[15] Çakmak S. Elektroeğirme. Hacettepe Üniversitesi Nanobülten Dergisi 2011; 13: 33-45.

[16] Muhammad HS, Muhammad S. The use of Lawsonia inermis linn. (Henna) in the management of burn wound infections. Afr J Biotechnol 2005; 4:934-937.

[17] Dabai YU, Muhammad S. Antibacterial activity of some Nigerian medicinal plants. Sci World J $2008 ; 3: 43-44$.

[18] Saadabi MAA. Evaluation of lawsonia inermis linn. (Sudanese henna) leaf extracts as an antimicrobial agent. Res J Biol Sci 2007; 2:419-423.

[19] Habbal OA, Al-Jabri AA, El-Hag AG. Antimicrobial properties of Lawsonia inermis: a review. Aust J Med Herbalism 2007;19:114-125.

[20] Güllüce M, Sökmen M, Daferera D, Ağar G, Özkan H, Kartal N, Polissiou M, Sökmen A, Şahin F. In vitro antibacterial, antifungal, and antioxidant activities of the essential oil and methanol extracts of herbal parts and callus cultures of Satureja hortensis L. J Agric Food Chem 2003;51(14):3958-65.

[21] Şahin F, Karaman I, Güllüce M, Öğütçü H, Şengül M, Adıgüzel A, Öztürk S, Kotan R. Evaluation of antimicrobial activities of Satureja hortensis L. J Ethnopharmacol. 2003;87(1):61-5.

[22] Bnyan IA, Abid AT, Obied HN. Antibacterial activity of carvacrol against different types of bacteria. J Nat Sci Res. 2014;4:13-6.

[23] Nostro A, Roccaro AS, Bisignano G, Marino A, Cannatelli MA, Pizzimenti FC, Cioni PL, Procopio F, Blanco AR. Effects of oregano, carvacrol and thymol on Staphylococcus aureus and Staphylococcus epidermidis biofilms. J Med Microbiol. 2007;56(4):519-23.

[24] Xu J, Zhou F, Ji BP, Pei RS, Xu N. The antibacterial mechanism of carvacrol and thymol against Escherichia coli. Lett Appl Microbiol 2008;47(3):174-9. 